\title{
"Educational Regionalization" and the Gated Global: The Construction of the Caribbean Educational Policy Space
}

Tavis D. Jules

Loyola University Chicago, tjules@luc.edu

Follow this and additional works at: https://ecommons.luc.edu/education_facpubs

Part of the Education Commons

\section{Recommended Citation}

Jules, Tavis D.. "Educational Regionalization" and the Gated Global: The Construction of the Caribbean Educational Policy Space. Comparative Education Review, 59, 4: 638-665, 2015. Retrieved from Loyola eCommons, Education: School of Education Faculty Publications and Other Works, http://dx.doi.org/ $10.1086 / 683025$

This Article is brought to you for free and open access by the Faculty Publications and Other Works by Department at Loyola eCommons. It has been accepted for inclusion in Education: School of Education Faculty Publications and Other Works by an authorized administrator of Loyola eCommons. For more information, please contact ecommons@luc.edu.

\section{(c) $($ () $\ominus$}

This work is licensed under a Creative Commons Attribution-Noncommercial-No Derivative Works 3.0 License. (c) Comparative and International Education Society, 2015. 


\title{
"Educational Regionalization" and the Gated Global: The Construction of the Caribbean Educational Policy Space
}

\author{
TAVIS D. JULES
}

\begin{abstract}
This article draws on "regime theory," particularly on the concepts of cooperation, compatibility of interests, and proclivity to compromise, to examine the rise of the Caribbean Educational Policy Space (CEPS). In making this argument, with the aid of a content analysis of 26 educational policies from the 15 member states of the Caribbean Community (CARICOM), this article first locates the different policy mechanism of external effects, or policy tools, within the regional policy environment that governs and regulates education at the national level to explain how these policy tools and mechanisms have given rise to a very distinctive form of what I call educational regionalism that frames the regional educational policy space in the Caribbean. The data show that CARICOM utilized the noneconomic process of functional cooperation, and the policy tools of lesson drawing, policy externalization, and policy transfer to respond to pressures of globalization across three different policy cycles and concludes by discussing the implications of such a policy maneuver for the integrative project of economic regionalism.
\end{abstract}

\section{Introduction}

This article draws on "regime theory" (Krasner 1983; Jules 2012), particularly on the concepts of "cooperation," "compatibility of interests," and "proclivity to compromise" of the convergence of regional actors' ideologies in order to examine the rise of the Caribbean Educational Policy Space (CEPS) in the post-2008 financial crisis era. In International Regimes, Stephen Krasner (1983) initially conceptualized a regime as a set of "principles, norms, rules, and decision-making procedures around which actors' expectations converge in a given issue area" (1). In this article, regime theory is applied to the regional level to suggest that regimes, once created, increase the probability of cooperation and collaboration by affecting the behaviors of actors (in the current context, states) through monitoring, reporting, and compliance.

I am grateful for the support of my colleagues Patrick S. Ressler, David Post, Andrew Shiotani, Kristin J. Davin, Lara Smetana, and my graduate assistants Landis G. Fryer and Teresa Barton, who provided comments on earlier drafts of this article, and to external referees who offered extensive critical feedback.

Received August 13, 2014; revised May 29, 2015; accepted June 19, 2015; electronically published September 29, 2015

Comparative Education Review, vol. 59, no. 4.

(C) 2015 by the Comparative and International Education Society. All rights reserved. 0010-4086/2015/5904-0004\$10.00 
In looking at the cooperation that takes place in education through the premises of state-driven regimes, I argue that CEPS illustrates the core tenants of regime theory through the consolidation of fragmented, balkanized, and borderless educational spaces. Thus, in the Caribbean Community (hereafter CARICOM) educational policy making that gives rise to CEPS, through discursive consensus, commences during the early 1990s in tandem with the rise of what Thomas Friedman (2005) has called "globalization 3.0,"1 where the emphasis is on global collaboration and competition amongst individuals, and continues through the inauguration of "the gated global" where governments have created impediments to globalization as they retreat to the regional level (Economist 2013). In making this argument, the article first locates the different policy "mechanism of external effects" (Dale 1999) or "policy tools" (Jules 2012) within the regional policy environment that governs and regulates education at the national level to explain how these policy tools and mechanisms give rise to a very distinctive form of what I call educational regionalism that frames the educational policy space in the Caribbean. Regime theory is employed to explain the rise of educational regionalization and how it is driven by supranational organizations and institutions or "trans-regional regimes—such as CARICOM" (Jules 2012, 2013) that are now part of educational governance and regulatory architecture fostering "regulatory state regionalism" (Robertson 2010). The rise of the gated global has solidified trans-regional regimes as a permanent part of the international landscape since these regional regimes have moved away from merely coordinating cross-border trade and now focus on coordinating multilevel foreign, regional, and national economic and social policies-the "coordination of coordination," according to Dale (2005)-and serve to buffer the policy-making influences of "international knowledge banks" (Jones 2004). Following Pankhaj Ghemawat (2011), I argue that globalization does not mean homogenization. Rather, the increasing uniformity of educational blueprints worldwide masks growing choices within them to which even international knowledge banks must adjust. Such a lens moves us away from the orthodoxy of regime theory as a tool with which to understand economic transnational relations, security, and global environmental challenges and instead enables us to examine the actors, discourse, and institutions which are a central component of trans-regional processes that, themselves, are part of the funding, provision, and synchronization of global policy mandates (Do Amaral 2010; Jules 2012; Verger et al. 2012). In adapting regime theory in this way, the article highlights how "policy audiences"- the people, agencies, and institutions who are the consumers

\footnotetext{
${ }^{1}$ Friedman (2005) argues that globalization 1.0 commenced with the opening of trade routes between the old and new worlds from the fifteenth century to the nineteenth century. Globalization 2.0, although interrupted by the Great Depression and two world wars, is dated from the turn of the nineteenth century to the end of the millennium.
} 
of policy (Jules 2013) — shape the policy environment with the movement from governance to government or "governance with and without government" (Djelic and Sahlin-Andersson 2006, 7). This extends our understanding of the ways in which the state is able to respond to the changing global policy environment.

Regime theory thus enables us to understand how regional discursive policy making in CARICOM utilizes various mechanisms of external effect to construct the CEPS, delineated by a "fabricated educational policy space" (Nòvoa and Lawn 2002). I identify these mechanisms as discursive policy tools (lessons-drawing, policy externalization, and policy transfer) and an active process (functional cooperation) that combats the external forces of globalization. Second, I argue that globalization 3.0 is creating new and idiosyncratic relationships between the national, regional, and international levels to engender policy reform within the Caribbean Single Market and Economy (CSME), another policy space under the purview of CARICOM. Third, I argue that the effects of economic globalization at the regional level have stimulated member states to create standard policy discourses to remain competitive in a knowledge-based global economic environment. In what follows, I briefly engage with theories of economic globalization and then describe my methodology for a content analysis of relevant educational policies. I use these data to show how CARICOM utilized the noneconomic process of functional cooperation and the policy tools of lesson drawing, policy externalization, and policy transfer to respond to pressures of globalization across three different policy cycles. Finally, I conclude by discussing the implications of such a policy maneuver for the integrative project of regionalism.

\section{Educational Regionalism: A Brief History}

The rise of the coordination, regulation, and governance of education at the regional level in the small (and micro) states of CARICOM dates back to the 1970s, when the exogenous consequences of economic globalization came to the Caribbean in the form of two oil crises in 1973 and 1979 and subsequent structural adjustment programs (SAPs) that included recommendations for privatization, deregulation, and liberalization of the national economies across the region. Endogenously, the regional challenge to development posed by such globalizing forces was economic ideological pluralism (as reflected in competing socialist and capitalist ideologies within the region). Since all CARICOM countries followed the recommendations of SAPs in detail, by the end of the 1980s many CARICOM countries faced similar problems and looked for common policy solutions to enter the emerging competitive knowledge economy. In 1989, CARICOM's Standing Committee of Ministers for Education (SCME) identified cooperation 
and collaboration as the preferred strategy for educational development in the region. Given the smallness of CARICOM's members, regional trade agreements (RTAs) enshrined in the "Treaty of Chaguaramas" are the driving forces toward the regional modernization project. In this way, transregional regimes such as CARICOM exist to facilitate the shaping of common policy responses to common regional problems while mitigating the unintended exogenous consequences of domestic policies. From the perspective of early globalization 3.0, the challenges of the knowledge society/ economy, lifelong learning education, teacher professionalization, accountability, equity, and efficacy (Simons et al. 2009) have been treated by national governments with diverse policy instruments, tools and processes, often in conjunction with the rise of protectionism.

Using cooperation to foster educational reform across the region laid the foundation for a common CARICOM educational space. In the Caribbean, borderless education became characterized as taking place in "the daily work of teachers and policy-makers, within shared regulations and funded projects" (Nòvoa and Lawn 2002, 20). In CARICOM, cooperation allows policy convergence to arise "through the coincident recognition and resolution of a common problem through the preexisting structures, and processes of an international regime" (Bennett 1991, 227). The movement toward a borderless educational space was seen as enabling the establishment of social solidarity through the development of a sense of a common cultural identity and increased social understanding. CEPS took shape when (i) the Grand Anse Declaration noted "that people, rather than institutions, are the creators and producers of development" (CARICOM 1989); (ii) CARICOM commissioned the Advisory Task Force on Education (ATFE; CARICOM 1993) to review the current state of education; (iii) the final report of the Task Force of Education was presented; (iv) and The Time for Action Report proposed education reform regionally along the lines of curriculum, teacher education, school management, finance, and the capabilities for policy research, analysis and monitoring (CARICOM 1992). The ATFE (CARICOM 1993) argues that relevant constituencies-that is, CARICOM membersshould be involved in crafting educational objectives, content, and arrangements appropriate to the contemporary needs and anticipated challenges of the region. The ATFE (CARICOM 1993) suggests "education is and will continue to be a critical factor in the national and regional efforts to sustain and enhance productivity and economic growth" (1). Regional policy advanced education as the field of cultural edifice congruent with the political project of regional integration and the construction of an "imagined community" (Anderson 1993). Within this new community, education is seen as a way in which "new identities or missions or spatial locations are assigned and produced" (Nòvoa and Lawn 2002, 6). However, as argued below, in looking at the regional level, the challenges to policy presented by globalization are 
given a collective regional response that is embraced by all member states via a shared discourse enabled by the CEPS.

\section{Approaches to Studying Educational Regionalism}

During globalization 2.0, a period from the end of World War II to around the time of the fall of the Berlin Wall and defined by declining nation-state influence and the rise of transnational corporations and multinationals (Friedman 2005), policy actors such as the World Bank and the International Monetary Fund became key players in the educational policy landscape and influenced the structure of education globally, leading to what Karen Mundy (1998) calls the "rise of educational multilateralism" and what Philip Jones (2004) identifies as the "era of International Knowledge Banks" (IKB). With the emergence of globalization 3.0 and the rise of labor mobility and global citizenship (Silova and Hobson 2014), we are seeing a contraction at the regional level leading to the proliferation of RTAs and the creation of regional trading blocs to protect national interests. Protectionism is one hallmark of a gated regional and gated global. With the rise of globalization 3.0, CARICOM concentrates on harmonizing the positions of its member states through consensus to face various challenges associated with the movement from Fordism to flexible accumulation or economic capitalism.

The existing debates about globalization in comparative and international education and its impact on education have focused on a dualist approach of pitting the national against the international. Current scholars of globalization use nation states as their unit of analysis, thus confining themselves to "methodological nationalism" (Robertson and Dale 2008). This response has created a vacuum that neglects the importance of regionallevel governance systems. While there is scholarly work on the impact of globalization at the regional level, it has focused on the role of regional integration of and policy challenges within industrialized countries, particularly the European Union (Dale 1999; Dale and Robertson 2002; Jakobi 2009), or the policy challenges facing international institutions at the heart of regional entities (Verger 2008; Jakobi 2009). In the new gated global, the emergence of the BRICS nations (Brazil, Russia, India, China, and South Africa) and the advancement of the ASEAN community (Association of Southeast Asian Nations) raises important questions about how regional trading blocs, especially those in the Global South (e.g., the African Union, the Andean Community, MERCOSUR, the Community of Latin American and Caribbean States [CLAC], the Union of South American Nations [UNASUR], and CARICOM) have responded to policy challenges created with the advent of globalization 3.0 and its multidimensional economic, technological, political, and cultural emphases. 
In light of the trajectories of globalization studies, the theory of educational isomorphism is combined with regime theory from international relations to develop the concept of "transregional regimes" as a new governance intermediary between studying the local and global. Current approaches to neo-institutionalist theory in comparative and international education offer the anamorphosis lens of the "globalization optique" (Carney 2009) that always moves from the global/local binary toward inclusion of the regional level. The globalization optique employed here suggests that neo-institutionalists see educational isomorphism as part of educational projects. Such a merger pays particular attention to how state structured interrelations and practices diffuse standardized "global scripts" or "templates" to create "conformity" (Drori et al. 2006), giving rise to a world culture shaped by the international system (Ramirez and Boli 1987). Neo-institutionalist scholars (Meyer et al. 1997; Boli and Thomas 1999; Ramirez and Meyer 2002) have established that global civil society and other international agents acting on behalf of globalization have significantly aided the creation of "global education" at a discursive level (Steiner-Khamsi 2000). Others have detailed the nature of globalization and its specific impact upon education policy making at the regional level (Dale 1999; Verger and Hermo 2010), often rereading educational policy texts at the regional level through critical educational policy studies (Dale and Robertson 2009; Simons et al. 2009).

The globalization process and tools or mechanisms that facilitate convergence have been under-theorized. To understand educational similarities across national levels at the regional level, Kerr's (1983) definition of convergence, as the "tendency of societies to grow more alike, and to develop similarities in structures, processes, and performances" is employed to comprehend how transregional regimes provide a platform for coordination, collaboration, and standardization in the form of harmonization of educational policy. Transregional regimes, like CARICOM, are viewed as large intraregional organizations whose members are sovereign countries contributing resources to the development of that group of countries through regional mechanisms and policy processes. They facilitate the exchange of policy ideas and act as multilevel governance institutions responding to the inability of national governments to control global, regional, and transnational economic processes. They create common regional policies that benefit members while providing common institutional frameworks for building consensus, including the establishment of frameworks (reducing transactional costs) and coordinating actors' expectations (improving quality and quantity of information available to states) as issues arise within the policy space. It is within this movement that we see the rise of new forms of negotiated regimes to govern and regulate cross border $(2000)$

${ }^{2}$ See Meyer et al. (1979); Ramirez and Boli (1987); Thomas et al. (1987); Meyer and Ramirez 
educational flows. The construction of regional projects has created new mechanisms to regulate and govern the ways educational policy making is conducted at the national level. In essence, the extant literature has not sought to investigate the policy processes and policy tools that a transregional regime like CARICOM has used to respond to any of the eras of globalization outlined here.

\section{Methods}

In focusing on the regional level, this research moves away from methodological nationalism, which limits the analysis to the policies and politics of the state and instead moves toward acknowledging the role of transregional regimes within educational policy making. Therefore, to gauge how CARICOM responds to the challenges of globalization, this article analyzes policy making at both the national and regional discursive level. Here, the discursive level is studied by examining policies as vital expressions of social power that epitomize the values of authoritative actors and institutions whose knowledge about the social world are echoed in these texts (Ball 1990). With reference to Michel Foucault, policy discourse, epitomized by the policies themselves, "can be said, and thought, but [is] also about who can speak, when, where and with what authority" (Ball 1990). While this is not a linguistically focused analysis, I highlight aspects of Critical Discourse Analysis, particularly the fact that policy knowledge is "socially constructed and shaped by relations of power that are both material and discursive" (Vavrus and Seghers 2010, 77) within the political context of the Caribbean. The focus of this article is thus on institutional discourse produced by national actors (ministers of education) since it is these actors who are, collectively, the drivers of change, gatekeepers, and custodians of the status quo. Therefore, individual and collective regional ideologies, made behind closed doors, and which are converging, do in fact direct and shape the national discursive agenda setting mechanisms since it is CARICOM ministers of education that have knowledge of national, regional, and global priorities and agenda-setting trends.

A content analysis of 26 educational policies from 13 CARICOM countries between 1990 and 2007 is the primary method to examine policy discourse and uncover the creation of the CEPS. In a content analysis, texts are classified into fewer content categories, and according to Robert Weber $(1990,12)$, "words, phrases and other units of text classified in the same category are presumed to have similar meanings." These categories became themes, and the objective was to specify what other texts were drawn upon in the constitution of the text being analyzed, and how they were being used (Fairclough 2006). As Weber $(1990,12)$ also contends, "to make valid inferences from the text, it is important that the classifications produced be 
reliable in the same way." The policies were chosen based on the following three criteria: (i) the 1988 Caribbean Advisory Task Force on Education produced their "Final Report on the Future of Education in the Caribbean" in 1993 (hereafter referred to as the regional policy); (ii) regionally, the 1989 "Grand Anse Declaration and Work Programme for the Advancement of the Integration Movement” in 1989 (hereafter referred to as the Grand Anse Declaration) endorsed by the CARICOM heads of government and created a platform for sweeping regional changes ranging from education to economic reforms; and (iii) internationally, in 1990 the "World Declaration on Education for All" (hereafter referred to as the international policy), where all CARICOM countries were signatories, became the new international standard for "direct action within individual countries, cooperation among groups of countries sharing certain characteristics and concerns, and multilateral and bilateral cooperation in the world community" (UNESCO 1990). The period 1990-2007 was further broken down into three smaller policy cycles based on policy renewal cycles: 199096, 1996-2002, and 2002-7 (see table 1 and fig. 1). To understand whether or not discursive educational policy convergence was taking place at the regional level, the regional policy and the international framework became the benchmarks of dominant discourse types across national policy texts. The aim was to understand whether or not national policies were converging along regional discursive policy lines or international policy lines through an analysis of the official national educational policies.

As table 2 shows, this study used a categorical and thematic content analysis of educational policy texts, which were classified to understand common themes and references to policy content. To enhance the reliability of the classifications, two coders ${ }^{3}$ used the same textual classifications. These classifications were derived from thematic categories based on the "actions required" headings of the regional and the international policies. Five thematic categories emerged from the analysis of the international policy: (i) assessing needs and planning action; (ii) developing a supportive policy environment; (iii) designing policies to improve basic education; (iv) financing of management, improving managerial, analytical and technological capacities; and (v) building partnerships and mobilizing resources. The regional policy produced five broad thematic categories as well: (i) levels of education; (ii) curriculum reform; (iii) teacher education; (iv) management and administration of schools; and (v) financing of education.

Next, the coders examined the national policies to locate the emergence of themes and corroborate the presence of the theme within the regional or international text. For example, in the regional document, a categorical heading entitled "levels of education" had the theme "administrative and

\footnotetext{
${ }^{3}$ The coders consisted of the lead researcher of the project and a trained local student, from the University of Guyana, that was trained by the researcher.
} 


\begin{tabular}{|c|c|c|c|}
\hline Country & Name of Policy Analyzed & Policy Period & $\begin{array}{l}\text { Number } \\
\text { of Pages } \\
\text { Analyzed }\end{array}$ \\
\hline Antigua and Barbuda & $\begin{array}{l}\text { Quality Public Education, Antigua and } \\
\text { Barbuda, } 2004 \text { and Beyond }\end{array}$ & $2004-9$ & 92 \\
\hline Bahamas & Manifesto 92 & 1992-97 & 5 \\
\hline Bahamas & $\begin{array}{l}\text { Manifesto II Agenda to and for the } \\
\text { 21st Century }\end{array}$ & 1997-2002 & 6 \\
\hline Bahamas & $\begin{array}{l}\text { Our Plan: A Strategy for Bahamas and a } \\
\text { Brighter Future }\end{array}$ & $2002-7$ & 5 \\
\hline Bahamas & $\begin{array}{l}\text { Strategic Plan 2004: Bahamian Education } \\
\text { in the 21st Century }\end{array}$ & $2002-7$ & 24 \\
\hline Barbados & National Development Plan & 1988-93 & 11 \\
\hline Barbados & National Development Plan & 1993-2002 & 41 \\
\hline Barbados & Strategic Plan 2002-12 & $2002-7$ & 117 \\
\hline Belize & Action Plan & $2005-10$ & 20 \\
\hline Dominica & $\begin{array}{l}\text { Education Sector Plan for Education } \\
\text { Development in the Commonwealth } \\
\text { of Dominica }\end{array}$ & 1989-94 & 80 \\
\hline Dominica & $\begin{array}{l}\text { Education Development Plan 1999-2005 } \\
\text { and Beyond }\end{array}$ & 1999-2005 & 190 \\
\hline Grenada & Education Policy Document Grenada & 1992-2002 & 35 \\
\hline Grenada & $\begin{array}{l}\text { SPEED 1: Strategic Plan for Educational } \\
\text { Enhancement and Development 2002-2010 } \\
\text { (ended in 2004) }\end{array}$ & $2002-4$ & 45 \\
\hline Grenada & $\begin{array}{l}\text { SPEED 2: Strategic Plan for Educational } \\
\text { Enhancement and Development 2006-2015 }\end{array}$ & $2006-15$ & 100 \\
\hline Guyana & State Paper on Education Policy & 1990-95 & 39 \\
\hline Guyana & $\begin{array}{l}\text { An Education Policy and Five Year } \\
\text { Development Plan for Guyana }\end{array}$ & 1995-2003 & 41 \\
\hline Guyana & Strategic Plan 2003-2007 & $2003-7$ & 67 \\
\hline Jamaica & Jamaica Five Year Development Plan & 1990-95 & 120 \\
\hline Jamaica & White Paper: The Way Forward & 2000-2000 & 17 \\
\hline Jamaica & Cooperate Plan 2002-2005 & $2002-5$ & 56 \\
\hline Montserrat & Education Policy & 1996 & 36 \\
\hline Montserrat & Work Plan for $1999 / 2000$ & 1999-2000 & 12 \\
\hline Montserrat & Work Plan for 2000-2001 & 2000-2001 & 17 \\
\hline Montserrat & Cooperate Plan 2004-2008 & 2004-8 & 11 \\
\hline Montserrat & Education Development Plan 2002-2007 & $2002-7$ & 66 \\
\hline St. Kitts and Nevis & Five Year Plan & $1993-98$ & 110 \\
\hline St. Kitts and Nevis & State Paper on Education & $1997-$ & 158 \\
\hline St. Kitts and Nevis & $\begin{array}{l}\text { Learning and Growing: The Long Term } \\
\text { Plan 1998-2011 }\end{array}$ & 1998-2011 & 263 \\
\hline St. Lucia & $\begin{array}{l}\text { Education Sector Development: } \\
2000-2005 \text { and Beyond }\end{array}$ & $2000-2005$ & 146 \\
\hline $\begin{array}{l}\text { St. Vincent and the } \\
\text { Grenadines }\end{array}$ & Education Policy & 1995 & 24 \\
\hline $\begin{array}{l}\text { St. Vincent and the } \\
\text { Grenadines }\end{array}$ & $\begin{array}{l}\text { Education Sector Development Plan } \\
\text { 2002-2007 (Volume } 1 \text { and 2) }\end{array}$ & $2002-7$ & 96 \\
\hline Trinidad and Tobago & Education Policy Paper 1993-2003 & 1993-2003 & 243 \\
\hline Trinidad and Tobago & Strategic Plan 2002-2006 & $2002-6$ & 81 \\
\hline
\end{tabular}

legislative guidelines for the effective operation of Early Child Education." To code for this theme in a national educational policy, it had to be explicitly or implicitly referenced at least once within the national text. In reference to this particular regional theme, an example of an implicit reference is il- 


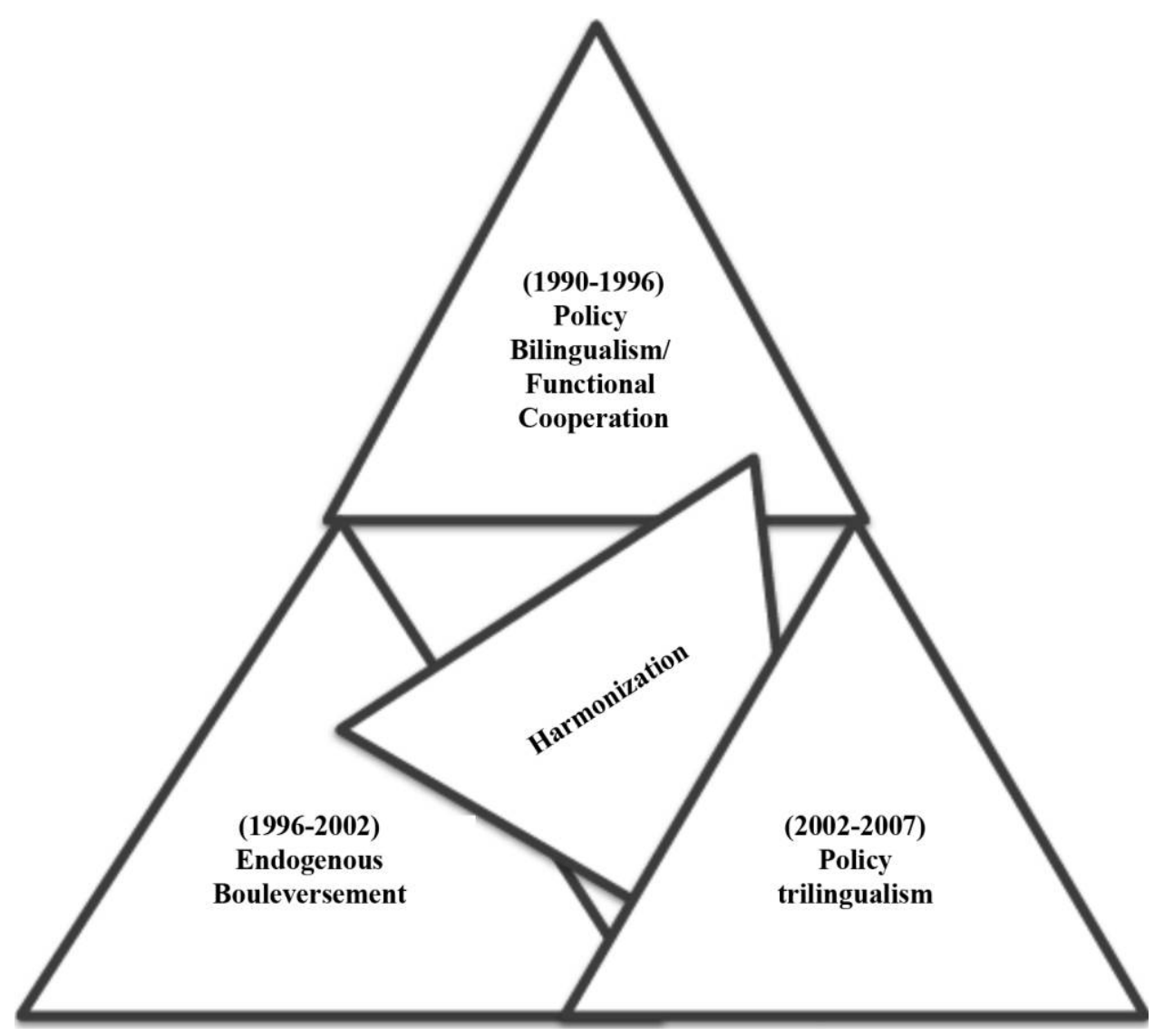

FIG. 1.-Tripartite diagram of findings

lustrated by the Bahamian Education Policy, which noted that the government will "revise existing guidelines for the establishing and operating of such facilities [early childhood centers] and enact the appropriate legislation to ensure that scholars learn in an appropriate and safe environment" (Government of Bahamas 1994, 3-4). In this instance, coders gave the theme a rating of " 1 " to indicate the theme was present in the national policy. If the theme was not present, the coders used a rating of " 0. ."

For the purposes of this study, the occurrence of congruence is the exact text (word for word), or the conceptual idea of one document present in another. Congruencies are defined as the full or partial existence of a conceptual policy idea (also known as a reference) found in the qualitative reading of national policies using the themes established in the regional and international policies. Thus, policy documents during each policy cycle were coded for the existence of policy congruence. For example, results showed 
Thematic Categories

\begin{tabular}{llr}
\hline Level & \multicolumn{1}{c}{ Thematic Category } & Subthemes \\
\hline Regional level & 1. Levels of education & 31 \\
& 2. Curriculum reform & 47 \\
& 3. Teacher education & 4 \\
4. Management and administration of schools & 6 \\
& 5. Financing of education & 8 \\
International level & 13 \\
& 2. Assessing needs and planning action & 4 \\
& 2. Developing a supportive policy environment & 10 \\
& 3. Designing policies to improve basic education & 5 \\
& analytical and technological capacities & 6 \\
\hline
\end{tabular}

that more regional congruencies than international congruencies existed during the 1990-96 policy cycle, and indicated more national policy references to the regional educational framework than to the international educational framework. The more explicit a congruence was in a policy document, the stronger its weight, thus the higher the quality of the reference. Thus, quality reference denotes the credence of congruence; only quality or high credence congruencies (that is, makes explicit reference) were included in this study. This theme-based approach to content analysis was used because it allows the study to locate the existence, occurrence, and congruence of a specific theme when comparing national policies with the regional and international policies.

In addition to policy documents, ten interviews were conducted over a seven-month period with regional policy officials. Interviews took the form of snowball sampling that was based on two criteria: $(a)$ interviewees had worked on the regional educational policy while it was being prepared and/ or $(b)$ worked at CARICOM during the time that the regional policy was written. These selection criteria were used to contextualize the regional climate during policy cycles under review. Additionally, several other secondary policy sources were consulted to enhance the picture of educational policy formation, the regional setting, and the political context that ultimately framed this study.

\section{Findings}

The content analysis of national educational policies found discursive convergence that mirrors regional developmental trajectories (see fig. 1). In other words, CARICOM members have sought to resurrect and utilize the noneconomic policy process of functional cooperation to engender the Caribbean Educational Policy Space. Functional cooperation has been carried out in the Caribbean since the 1940s, evident in the creation of regional institutions such as the University of the West Indies (UWI) and the West In- 
dies Shipping Association (WISA). In the Original Treaty of Chaguaramas (CARICOM 1973), functional cooperation was the noneconomic mechanism for the establishment and operation of common services and standards such as education, health, and secondary school examinations. By the 1990s, given the small size of CARICOM members, functional cooperation served to avoid wasteful duplication of expenditures in common policy areas and encouraged the flow of exchange by pooling ideas. Today, functional cooperation forms a core part of the gated regional and calls for a more efficient operation of common services and activities carried out for the benefit of the people - that is, the accelerated promotion of greater understanding, the advancement of social, cultural, and technological development, and intensified activities in areas such as health, education, and transportation (CARICOM 2001).

Accordingly, CARICOM (2007) notes that functional cooperation operates in rules-based enterprises such as the CSME since it provides "flexibilities to advance certain features of the Community's agenda, such as enhancing community solidarity, emphasizing common goals among politically and culturally distinct groups and mitigating power imbalances among neighbors" (6). For CARICOM, functional cooperation promotes international values, best practices, and global competitiveness of human resource development (HRD). Moreover, functional cooperation as a process is what shapes the creation of the "ideal Caribbean person" (CARICOM 1997a) to function within the CSME. In essence, CARICOM uses the policy process of functional cooperation to achieve its aims of integration while seeking to compete globally. Through different policy cycles, and with the aid of the policy process of functional cooperation at the regional level, laboratories of lived experiences of globalization were created within CARICOM.

Regarding education policy, the findings demonstrate that CARICOM members have engaged in the operationalization of functional cooperation as the process for deeper integration since the report by ATFE (CARICOM 1993). Several policy tools aided this process. As figure 1 suggests, the contextual explanations of the results drew on existing theoretical frameworks and identified them as policy tools to describe the following policy cycles: lessondrawing (Rose 1993) from 1990 to 1996, policy externalization (Schriewer 1990; Steiner-Khamsi 2004) from 1996 to 2002, and policy transfer (Dolowitz and Marsh 1996) from 2002 to 2007. These three different policy tools were evident across national educational policies, and over time, the tool used for each policy cycle built upon its predecessor and was often redefined; yet the noneconomic policy process - functional cooperation-remained consistent. The central argument is that the policy tools and the policy processes gave rise to a tripartite policy language that was simultaneously spoken by national states to appease national constituents, a transregional regime, and international knowledge banks. In other words, since changes occur over the short span 
of policy cycles, the institutional isomorphism detected in national policies is based upon consensus.

\section{Discussion}

The discussion chronicles the development of the Caribbean educational policy space over the course of three policy cycles and does so with reference to the policy scholarship on lesson-drawing, policy externalization and policy transfer.

\section{Phase 1: 1990-1996 Policy Cycle: Intensified Functional Cooperation}

As member states sought to reform their educational systems, policy reformation was premised around deeper integration informed by lessondrawing between member states. In the 1980s, the fundamental changes at the global level created conditions in which economic well-being had become increasingly dependent on the availability of a highly educated and highly skilled labor force capable of being retrained to meet the demands of regional integration (Hall 2003, xiii). Cooperation became intensified as the confidence of member states declined with the "flight of human and financial capital, reduction of production and productivity and the emergence of a large underground sector in the economy" (CARICOM 1984, 2). Against this backdrop, member states sought to reform their educational systems. This new development path spun a plethora of regional declarations and regional understandings, as well as a general consensus about how to deal with exogenous influences. As the region moved closer toward a single economic space, the 1989 Grand Anse Declaration called for the "immediate activation of Article 39 of the Annex to the Treaty of Chaguaramas ... in order to promote consultation, cooperation and coordination of policies at the macro-economic, sectoral and project levels" (CARICOM 1989, 2). It further noted that, "in examining the longer term prospects for development, [regional leaders] recognize the primary importance of HRD and the expansion of scientific and technological capability to the modernization of the regional economy" (CARICOM 1989, 3). The new era of development began in the 1990s with the region undertaking internal reform of its educational systems in order to combat exogenous and endogenous forces. Thus, this initial policy cycle is categorized as one of intensified functional cooperation as national emphases shifted from economic integration toward enhancing human resources regionally.

The first steps toward internal regional policy reform in education occurred when the then Secretary-General of CARICOM, Edwin Carrington, commissioned an ATFE to conduct consultations on the state of education across the region. The ATFE outlined and managed the activities and events required in a continuing process of regional consultation and analysis. The 
Standing Committee of the Ministers of Education (SCME) suggested that a coordinated regional approach be adopted to implement the educational policies and programs identified during the inquiry by the ATFE (SCME 1988). Moreover, members had to be clear about each nation's individual need, while mechanisms would be established to devise methods of addressing these needs, utilizing national training facilities as components in regional networks intended to be the backbone of intensified cooperation. SCME 7 further encouraged member states to pay greater attention to strengthening their educational systems at all levels by offering opportunities to acquire skills that would directly contribute to modernizing and developing the regional economy (SCME 1988).

Based on the above context, intensified functional cooperation describes the 1990-96 policy cycle since exogenous pressures (economic globalization, SAPs, the end of the Cold War, and the realignment of Europe) forced member states to reaffirm their commitment to integration by drawing intraregional lessons from each other. As external pressure to reform education took root during the 1990-96 policy cycle, member states sought to draw "lessons of history" from each other (Rose 1993). Lesson-drawing as a policy tool is defined as "a program for action based on a program or programs undertaken in another city, state, or nation or by the same organization in its own past" (Rose 1993, 21). The findings show that lesson-drawing commenced when the SCME 7 agreed to embark on a "coherent and conscious, and systematic program of inquiry, analysis, diagnosis, and design" (SCME 1988). Thus, lesson-drawing aided the policy process in the following ways: (i) acquiring, commissioning, and developing teaching materials to meet common trends; (ii) supporting individual students through mutual accreditation procedures; (iii) assisting in the development of local support services; (iv) developing in staff training institutionally, supporting live twoway communication links between universities and colleges; (v) providing an information service; and, (vi) integrating evaluation and applied research. Moreover, the process of functional cooperation was codified by the efficient operation of common policies, procedures, and strategies across the region. In this way, lesson-drawing during this policy cycle was the policy tool that allowed member states to respond to exogenous influences while intensifying their intrastate cooperative activities.

Lesson-drawing also took the form of national consultations on education. These consultations culminated in the creation of a regional educational policy in 1993 - the "Future of Education in the Caribbean"-in which member states were expected to take further lessons if they were to succeed with the integration project. National consultations became arenas of information sharing in which the ATFE obtained insights on key education issues, concerns, plans, and programs for the development and improvement of educational systems across the region. Through these consul- 
tations, inspiration from an existing program allowed for the combination of recognizable elements of that program (hybridization) with the familiar elements of a different program into a distinctive whole (synthesis).

This was typified during the Barbados consultations in 1993 when the ATFE noted that the concerns expressed by Barbados at various educational levels (i.e., preprimary, primary, secondary, tertiary, curriculum, measurement and evaluation, and planning) were common across the region (Special Meeting SCME 1993). Additionally, the members of the ATFE urged national education officials to document, for the benefit of other member states, two successful educational ventures in Barbados: the amalgamation of schools and the introduction of computers in primary and secondary schools. In evaluating the Barbados experience, lessons were drawn because the members of the ATFE saw how the program operated in place $\mathrm{X}$, and therefore they could hypothesize about its likely future effects in place Y. Rose (1993) refers to this process as the "fungibility" of a program based on policy prescriptions, which were treated as universally valid-that is, the model was expected to work in the same way irrespective of time and space. Fungibility became applicable to CARICOM experience in that all member states shared common goals, but also as member states mitigated transactional costs, they relied on and learned from each other and from the lessons of their past. "In this way the existence of common problems, defined in terms sufficiently abstract so that generic solutions appear applicable everywhere" (Rose 1993, 35) framed the policy solution. Thus, as CARICOM continued integrating, it became easier for programs to be externalized and eventually fully transferred from one policy level (national, regional, global) to another.

\section{Phase 2: 1996-2002 Policy Cycle: Endogenous Bouleversement}

Between 1996 and 2002, member states of CARICOM tried to align the reforms of 1990-96 with regional aspirations for human resource development. Accordingly, they thought that the regional policy endorsed by the Special Meeting SCME (1993) would guide their educational achievements for an unspecified time. However, four years later, member states returned to the collaborative table, took up the process of functional cooperation, and adopted a different policy tool. This was a radical break from the previous period since, rather than maintaining unidirectional lesson-drawing during the 1996-2002 policy cycle, member states now sought to externalize directives from the national level to the regional level and then back from the regional level to the national level. Member states exported and imported policies horizontally across national levels while shifting their developmental emphasis toward human capital and resource development in light of the prevailing global trends of neoliberalism that stress service mobility. To begin this shift, CARICOM members went back to an inspired source from 
the period of intensified functional cooperation, which seems to have been bypassed in favor of lesson-drawing and member exchange. The "Montego Bay Declaration" spoke to the greater importance of the regional level and called for "modern and relevant programs of education and training at all levels and for all age groups... which will equip our people to acquire the competencies to function effectively in the emerging knowledge-based economy" (CARICOM 1990, 2). Additionally, it called for a focus on "science and technology and the advances in telecommunications" to "[create] the Caribbean person who will have among other attributes, the capacity to improve and maintain physical, mental, social and spiritual well-being." Further, the Montego Bay Declaration noted, "in the global economy that is evolving, [Caribbean leaders] resolve to unite [their] best efforts to plan strategically to position [their] countries to take the fullest advantage of market niches, other global opportunities and sources of capital" (CARICOM 1990, 3).

Subsequently, CARICOM leaders committed themselves to the measures in the "Creative and Productive Citizens for the Twenty-First Century" (CARICOM 1997a) and the "Report on Human Resource Development and Science and Technology" (CARICOM 1997b). In this way, the 19962002 policy cycle sought to codify a collective regional response to educational directives to form the "ideal Caribbean person" (CARICOM 1997a). This is one who respects human life as the foundation on which all of the other desired values must rest; is psychologically secure; values differences based on gender, ethnicity, religion and other forms of diversity as sources of strength and richness; is environmentally astute; is responsible and accountable to family and community; has a strong work ethic; is ingenious and entrepreneurial; has a conversant respect for the cultural heritage; and exhibits multiple literacies, independent, and critical thinking to the application of science and technology as well as problem solving (CHGCC 19th Meeting 1998).

The beginning of the 1996-2002 policy cycle was characterized by a shift away from educational reform at the national level toward reform at the regional level, and "the regional integration process [was] seen as a collective instrument for the expanding and exploiting of opportunities for the fuller and more productive lives of our peoples" (CARICOM 1990, 3). During this cycle, educational externalization in CARICOM was correlated to the endogenous pressure to perform. In reflecting upon the phenomenon of convergence, Schriewer and Martinez (2004) and Steiner-Khamsi (2004) expand upon Luhmann and Schorr's (1979) concept of externalization to support their claims that educational policy isomorphism is discursive, and that it occurs when countries look beyond their national boundaries for solutions to internal educational crises. As Schriewer (2002) notes, the externalization concept is "system-related reflection that selectively emphasize 
certain societies and their institutions with a view to transmuting them into standard-setting modules." In other words, exogenous systems become a point of self-reference for states in crisis. Policy externalization, or making reference to other systems, functions as a last source of authority. These systems, as in the case of CARICOM, use self-descriptors to organize themselves into meaning-based social reality. Thus, educational theorizing within this context is "self-referential reflection of society's particular sub-system for education perused within that system" (Schriewer 2003, 276).

Using Phillips's (2004) typology, externalization in the region followed a specific trajectory. First, global pressure stimulated reform impulses for educational performance. The Second Special Meeting of SCME (1997) noted that the prevailing trends with respect to HRD in the region were numerous. As such, the upgrading of human resources was identified as a priority if the member states were to surmount the global challenge. The development of human resources would be both a cause and an effect of "economic development... [to] ensure opportunities and incentives for all citizens" (Second Special Meeting of SCME 1997, 13). Second, when Conference of Heads of Government of the Caribbean Community (CHGCC) 18th Meeting recognized that knowledge had become the central factor of competitiveness, they sought a theoretical understanding of the issue. This led CHGCC 18 to emphasize the importance of "life-long learning and continuing education as well as the need to develop and apply science and technology to the production of goods and services" $(1997,3)$. In recognizing that a potential problem existed, CHGCC 18 made the decision to create a regional model from which member states could borrow specific elements and tailor those elements to their individual national contexts. Ultimately, the regional model would govern all the member states. In this way, CHGCC 18 committed itself to the implementation of specific measures identified in the regional policy documents "Towards Creative and Productive Citizens for the Twenty-First Century" and "Human Resource Development and Science and Technology within the Context of the Single Market and Economy." CARICOM notes that globalization and the emergence of high technology economies impacted the way of life in the Caribbean Community, and for this reason it was important for the community to develop its human resources for the improved application of science and technology to all aspects of development (CARICOM 1997b). In endorsing the report, the CHGCC 9th Inter-Sessional Meeting (1998), reiterated the critical role of science, technology and HRD in achieving the economic and social goals of the Community. This meeting stressed the need to concentrate on areas in which the Caribbean had a comparative advantage. Regional institutions began identifying strategic priorities around which member states could seek to build and further strengthen their science and technology capabilities and infrastructures. 
Third, after the problem had been defined, CHGCC 18 agreed on a number of measures for priority implementation. Examples include the attainment of 15 percent enrollment of the postsecondary group in tertiarylevel education by the year 2005 and universal quality secondary education by the same year. These measures emphasized the relevance of education and training and the region's ability to develop creative and adaptable individuals while producing skilled labor for the key economic sectors of industry, agriculture, and, in particular, tourism (CHGCC 18th Meeting 1997). National machineries to monitor the implementation of national programs were agreed upon, and a high-level technical group was established at the regional level to monitor the achievement of goals and evaluate the impact of education programs.

Finally, once these three stages were completed, the next iterations of member states' national educational policies were externalized, and references were made to the necessary elements that had been legislated by 2002. For example, the World Bank contended that regional collaboration involved "promoting the concept of the Ideal Caribbean Person-recognizing the central role of education in the construction of social mentalities and nurturing regenerative capacities" (CARICOM 1997a, 32). Additionally, it observed that the challenge was not about economic competitiveness, but about strengthening higher standards of excellence in social development. In this way, by highlighting the strengths inherent in each national educational system, the document "glorified" the overall regional framework (Steiner-Khamsi 2000). Thus, the vision of the "ideal Caribbean person" (CARICOM 1997a) was seen as a regional framework that could address the educational deficiencies and challenges faced by individual member states. As policy externalization took place in the 1996-2002 policy cycle, it was further engendered by global competition that gave rise to policy trilingualism.

\section{Phase 3: 2002-2007 Policy Cycle: Policy Trilingualism}

The CSME calls for the free movement of skilled persons throughout the region, giving rise to issues of skill development through Technical and Vocational Education and Training (TVET), and the portability of regional qualifications for nationals to participate in the knowledge economy. To achieve a common system and understanding of quality assurance, standardization must be set at the national and regional levels for all areas of education and training, including TVET. CHGCC 27th Meeting (2006) calls for the dispelling of the immediate free movement of all categories to allow qualified regional nationals to be free to move throughout the region for employment and development. The Council for Human and Social Development (COHSOD) 15 considered the issue of International Labor Organization (ILO) guidelines through the establishment of Social Floor/Labor 
Standards in which member states were advised to adhere to in order to ensure that CARICOM nationals who moved for employment purposes were not treated unfairly. As such, CARICOM adopted a Declaration on Labor and Industrial Relations Principles, which highlighted the labor standards to which the region aspired and further served as a guide to enact harmonized labor legislation (CARICOM 1995). However, the standards on workers' rights agreed upon in Article XIX of CARICOM's Charter of Civil Society were not made mandatory for workers in all member states (CARICOM 1997b). In this way, the community agreed to harmonization in principle and did not unify labor legislation because there was consensus among member states that similar legislative provisions in all countries would be sufficient to ensure that workers would enjoy similar rights and protections across the Community. However, by 2006, CARICOM member states had adopted four ILO Model Labor Laws (termination of employment; nondiscrimination and equality in employment; recognition of trade union and employers' organizations; and occupational health, safety and the working environment) that were prepared in cooperation with the ILO-Caribbean Office. Subsequently, these model labor laws were enacted to varying degrees in member states. During this period, Guyana, for example, had enacted all four of the ILO Labor Acts, while other member states had enacted from one to four.

Overall, CARICOM regional agreements called for the respect and adherence to international labor standards. The most notable agreements were Article 73 (Industrial Relations and the Charter of Civil Society) and Article 39 (Workers' Rights) of the Revised Treaty of Chaguaramas (CARICOM 2001). The treaty goes beyond adherence by indicating in Article 226 (General Exceptions) that member states have the right to adopt and enforce measures relating to products of prison labor and child labor. Here the national and regional policy discourses came into conflict. Although a minimum set of standards should have formed the social floor in the Community, COHSOD did not sign off at the regional level. It is within this context of trying to appease both national member states and international donor agencies that policy transfer arose as a policy tool utilized by CARICOM to increase national policy integration.

Findings demonstrate that policy transfer arises as a consequence of structural forces (Stone 1999). David Dolowitz and David Marsh (1996) use the concept of "policy transfer" as a generic framework to encompass a range of related concepts (Evans 1999; Evans 2004; Beach 2006). According to Dolowitz and Marsh, the different forms of policy transfer include "lesson-drawing" (Rose 1993), "policy band-wagoning” (Ikenberry 1990), "policy borrowing” (Cox 1999; Steiner-Khamsi 2004), "policy shopping” (Freeman 1999), "systematically pinching ideas" (Schneider and Ingram 1988), and "social learning" (Haas 1992; Common 2004). Definitions of these terms 
all convey the sense that policy transfer is voluntary. In this analysis, policy transfer is "the process by which knowledge about policies, administrative arrangements, institutions and ideas in one political system (past or present) i used in the development of policies, administrative arrangements, institutions, and ideas in another political system" (Dolowitz and Marsh 1996, 344). Gita Steiner-Khamsi (2000) writes "what is being transferred ... is not so much a particular model of education, but the political discourse embedded in a particular education program." With an eye toward illuminating and building upon Gita Steiner-Khamsi and Ines Stolpe's (2006) work on reform bilingualism, and a focus on how the global is incorporated into the national and regional spheres, it is suggested that the members of CARICOM were able to develop trilingual educational policy between 2002 and 2007.

Analysis of national policies during the 2002-7 policy cycle suggests that CARICOM member states spoke a national, regional, and international language simultaneously, each geared toward a different policy audience. This supports conclusions reached by Steiner-Khamsi and Stolpe (2006) who, analyzing the local policy context to understand the meaning of globalization to local actors in the Mongolian context, differentiated between "local" and "global" audiences. They observed contours of "reform bilingualism," which they defined as "a universal language addressed to international donors, and a native language of reform that resonates with citizens" (Steiner-Khamsi and Stolpe 2006, 203).

An analysis through the lens of reform bilingualism shows that the proliferations of national and regional references to the international community were self-induced. In the case of CARICOM's member states, policy transfer did not mean wholesale copying of educational policies; in most textual instances only the policy names of international models were maintained. Thus, new words (such as stakeholder participation, best practices, equity, and assessment) entered the regional and national lexicon. The transfer of these words from the international to the national and regional policy levels signaled to the international community that the region and national governments were in agreement with them. Consequently, this assumed agreement attracted national funding. For example, the ratification and eventual transfer of the Core ILO Conventions by most member states facilitated the automatic establishment of a social floor for workers' rights within the CSME. As such, it was noted that future COHSOD meetings would be asked to determine whether the ILO's Conventions should be enacted into domestic legislation and if member states should put in place appropriate follow-up and enforcement mechanisms. During the policy process, national policies came into conflict with regional policies, which conflicted with international policy frameworks. The solution to the conflicts was that ILO regulations had to be accommodated at both the na- 
tional and regional levels, and national levels would have to adhere to regional standards that were yet to be determined.

As competition took root in the region, national policies spoke three different policy languages; they minimized scrutiny of the national policy; and maximized their exposure to competition and diminished their risk. In this way, national governments sought to protect themselves while enjoying the benefits of the regional and international policies and frameworks. If the regional or international protested that a specific policy issue was not being addressed, then national governments could have refuted this by referring to their respective policies.

In retrospect, national governments in the 2002-7 policy cycle sought to appease both the regional and international actors. In the case of CARICOM's member states, policy transfer did not mean wholesale copying of educational policies; in fact, in most instances, only the policy names of international models were maintained, creating dummy policy transferincorporating the names of international standards and so-called international best practices into the national vocabulary-without having to actually implement international standards.

\section{Conclusion}

The Caribbean Educational Policy Space came into being over the course of the three policy cycles outlined here. In the first cycle (1990-96), the process of functional cooperation intensified as the ATFE held national consultations on education across the region between 1988 and 1993 and drew lessons on education from member states that involved the widespread views of objectives, content, and arrangements that were appropriate to contemporary needs and anticipated future challenges. Pressures to reform educational systems in the mid-1980s gave rise to greater cooperation among CARICOM states. The second cycle (1996-2002) began as internal and external reform and cooperation pressures increased, leading to internal policy upheavals across the region. This led CARICOM member states to externalize policies and practices as they continued to utilize the process of functional cooperation to craft educational policy, which set the framework for the creation of the ideal Caribbean citizen. It is through deeper cooperation that the final regional policy was derived, and each member state imported and exported regional directives to assist their individual national objectives. As member states undertook educational reforms, they kept the "goals" of the larger community in mind.

Finally, the third cycle of reform (2002-7) gave birth to trilingualism as member states continued to maintain the façade of international models while adopting regional modes through policy reference, which strength- 
ened their own national models. Educational policies were repackaged by CARICOM countries under the guise of "global speak" but with the intention of being regionally adopted. The global nature of these policies intended to appease the IKBs, which service every member of CARICOM. Steiner-Khamsi (2003) argues that three prototypes of policy reactions exist: scandalization (the highlighting of weaknesses within one's own educational system via comparison), glorification (highlighting its strengths as a result of comparison), and indifference (lacks resonance within the educational system). Thus, policy trilingualism asserts that policy reaction to existing references (e.g., technical and vocational education, accreditation, access, quality) that were already part of the regional framework became "glorified," while those not on the regional agenda were ignored or not implemented.

Given these different phases within the life of CEPS, the implications of how globalization manifests at the regional level suggests a "semantics of harmonization" (Jules 2008) that has led member states to create the charisma of a solitary policy space when in reality they were being forced to conform to external policy pressures. Whereas the semantics of globalization promotes the "de-territorialization and de-contextualization of reform, and challenges the past conception of education as a culturally bounded system" (Steiner-Khamsi 2000, 2), actual policy prescriptions enact these visions, often via a rhetoric of renewed patriotism; one that claims that the nation-state must transcend national boundaries in order to survive economically and politically. The effectualness of the semantics of globalization rest in the fact that policy analysts and practitioners often resort to a new sort of patriotism, one that claims that the nation-state must transcend national boundaries in order to survive economically and politically in today's globalized society. First, I concur that trans-regional regimes such as CARICOM are "capsules in which rational actions take place" (Breslin et al. 2003, 7) by rational actors. Rational actors (state and nonstate alike) now function across multilevel policy systems that are driven by different educational governance tools or mechanisms (funding, provision, ownership, and regulation), across different scales (local, regional, and global) bounded together by the division of labor and incubated within the General Agreement on Trade in Services (GATS). Second, I suggest that the semantics of harmonization are not just a functional spillover from integration but, rather, conscious policy decisions reflecting regional identities aimed at engendering specific responses to exogenous pressures. Thus, I am suggesting that in the semantics of harmonization, we are seeing a new form of reterritorializing of temporal space that is regional in scope, scale, and dynamics since today's global environment is multiscalar, multispacial, and multilayered and guided by collaboration and consensus. In other words, 
like the story of Goldilocks, the regional level is often mediating between the national and global spaces; therefore, it is not too hot, not too cold, but just right (Breslin et al. 2003).

As such, regional reterritorializing has significant consequences for actorhood, structure, and discourse in that the scalar space that it now occupies - that is, the return to gated protectionism - is one driven by educational regionalism. In other words, globalization is now being used at the regional level as a first-order response; adjusting to the emergent global political architecture (Grugel and Payne 2000). As this study suggests, policy convergence at the regional level is a fabricated process rather than a result of progressive and linear stages of industrialization. Regional reterritorializing is not about bounded territorial claims but about the maximization of geographic space to stay competitive in a service-dominated era. As CARICOM member states reformed their educational systems over the last 15 years, they paid attention to the domestic level, the regional level, and the international level and in trying to appease all three policy levels and secure funding, CARICOM states created an inorganic harmonization process along predetermined lines. Thus, in the end, educational policies across the region-in responding to globalization-became trilingual in nature as the nation-state changed and policies developed.

Finally, this study questions if globalization is real and active. Can countries in CARICOM globalize at levels above the nation-state but below the international level, that is, can they "g-regionalize"? In this context, "g-regionalization" refers to the interplay between regional histories (which is a composition of several national idiosyncratic histories) and broad global trends. In other words, with the advent of globalization 3.0, we are seeing the movement toward discursive educational harmonization of policies, processes and performances as transregional regimes become de facto among small states competing in a large world.

\section{References}

Advisory Task Force on Education (ATFE). 1993. The Future of Education in the Caribbean. Georgetown, Guyana: CARICOM.

Anderson, Benedict. 1993. Imagined Communities. London: Verso.

Ball, Stephen J. 1990. Politics and Policy Making in Education. London: Routledge. Beach, J. 2006. "The Theme of Educational Transfer in Comparative Education: A View over Time." Research in Comparative and International Education 1 (1): 2-13.

Bennett, C. 1991. "What Is Policy Convergence and What Causes It?" British Journal of Political Science 21 (2): 215-33.

Boli, John, and George M. Thomas, eds. 1999. Constructing World Culture: International Nongovernmental Organizations since 1875. Stanford, CA: Stanford University Press. 
Breslin, S., R. Higgott, and B. Rosamond. 2003. "Regions in Comparative Perspective." In New Regionalism in the Global Political Economy: Theories and Cases, ed. S. Breslin, C. W. Hugues, N. Phillips, and B. Rosemand. London: Routledge.

CARICOM. 1973. Original Treaty of Chaguaramas. Georgetown, Guyana: CARICOM. http://www.caricom.org/jsp/community/original_treaty.jsp? menu = community.

CARICOM. 1984. The Nassau Understanding: Structural Adjustment and Closer Integration for Accelerated Development in the Caribbean Community. Georgetown, Guyana: CARICOM. http://www.caricom.org/jsp/communications/meetings_statements /nassau_understanding.jsp?menu $=$ communications.

CARICOM. 1989. Grand Anse Declaration. Georgetown, Guyana: CARICOM. http:// www.caricom.org/jsp/communications/meetings_statements/grand_anse_dec laration.jsp?menu $=$ communications.

CARICOM. 1990. The Kingston Declaration. Georgetown, Guyana: CARICOM. http:// www.caricom.org/jsp/communications/meetings_statements/kingston_declaration .jsp?menu $=$ communications.

CARICOM. 1992. Protocol of Port of Spain. Georgetown, Guyana: CARICOM. http:// www.caricom.org/jsp/secretariat/legal_instruments/protocolofportofspain.jsp ?menu $=$ secretariat.

CARICOM. 1995. Declaration of Labour and Industrial Relations Principles. Georgetown, Guyana: CARICOM. http://www.caricom.org/jsp/secretariat/legal_instruments /declaration_labour_principles.jsp.

CARICOM. 1997a. "Creative and Productive Citizens for the Twenty-First Century." Paper presented at the Ninth Intersessional Meeting of the Conference of Heads of Government of the Caribbean Community, St. George's, Grenada.

CARICOM. 1997b. "Technology within the Context of the Single Market and Economy." Paper presented at Ninth Intersessional Meeting of the Conference of Heads of Government of the Caribbean Community, St. George's, Grenada.

CARICOM. 2001. Revised Treaty of Chaguaramas. Georgetown, Guyana: CARICOM. http://www.caricom.org/jsp/community/revised_treaty.jsp? menu = community.

CARICOM. 2007. Needham's Point Declaration. Georgetown, Guyana: CARICOM. http://www.caricom.org/jsp/communications/meetings_statements/declaration _on_functional_cooperation.jsp.

Carney, Stephen. 2009. "Negotiating Policy in an Age of Globalization: Exploring Educational 'Policyscapes' in Denmark, Nepal, and China." Comparative Education Review 53 (1): 63-88.

CHGCC 18th Meeting (Conference of Heads of Government of the Caribbean Community 18th Meeting). 1997. "Communiqué Issued at the Conclusion of the Eighteen Meeting of the Conference of Heads of Government of the Caribbean Community." Montego Bay, Jamaica: CARICOM. http://www.caricom.org/jsp /communications/communiques/18hgc_1997_communique.jsp.

CHGCC 19th Meeting (Conference of Heads of Government of the Caribbean Community 9th Intersessional Meeting). 1998. "Communiqué Issued on Conclusion of the Ninth Intersessional Meeting of the Conference of Heads of Government of the Caribbean Community." St. George's, Grenada: CARICOM. http://www.caricom.org/jsp/communications/communiques/9inthgc_1998 _communique.jsp. 
CHGCC 27th Meeting (Conference of Heads of Government of the Caribbean Community 27th Meeting). 2006. "Communiqué Issued at the Conclusion of the Eighteen Meeting of the Conference of Heads of Government of the Caribbean Community." Bird Rock, St. Kitts and Nevis: CARICOM. http://www.caricom .org/jsp/communications/communiques/27hgc_2006_communique.jsp.

Common, Richard K. 2004. "Organizational Learning in a Political Environment: Improving Policy Making in UK Government.” Policy Studies 25:72-97.

Cox, Robert. 1999. "Transfer and Models of Welfare Reform." Paper Presented at the Conference on Global Trajectories: Ideas, International Policy, Florence.

Dale, Roger. 1999. "Specifying Global Effects on National Policy: A Focus on the Mechanisms." Iournal of Education Policy 14:1-17.

Dale, Roger. 2005. "Globalisation, Knowledge Economy and Comparative Education." Comparative Education 41 (2): 117-49. doi:10.1080/03050060500150906.

Dale, Roger, and Susan Robertson. 2002. "The Varying Effects of Regional Organizations as Subjects of Globalization of Education." Comparative Education Review 46 (1): 10-36.

Dale, Roger, and Susan Robertson, eds. 2009. Globalization and Europeanization in Education. Oxford: Symposium.

Do Amaral, Marcelo Parreira. 2010. "Regime Theory and Educational Governance: The Emergence of an International Education Regime." International Educational Governance International Perspectives on Education and Society 3679:57-78. doi:10 .1108/S1479-3679(2010)0000012006.

Dolowitz, David, and David Marsh. 1996. "Who Learns from Whom: A Review of the Policy Transfer Literature." Political Studies 44:343-57.

Drori, Gili S., John W. Meyer, and Hokyu Hwang, eds. 2006. Globalization and Organization: World Society and Organizational Change. Oxford: Oxford University Press.

Djelic, Marie-Laure, and Kerstin Sahlin-Andersson, eds. 2006. "Introduction: A World of Governance: The Rise of Transnational Regulation." In Transnational Governance: Institutional Dynamics of Regulation. Cambridge: Cambridge University Press.

Economist. 2013. "The World Economy: The Gated Globe." Economist, October 12. Evans, Mark. 1999. "Understanding Policy Transfer: A Multi-Level, MultiDisciplinary Perspective." Public Administration 77 (2): 361-86.

Evans, Mark, ed. 2004. Policy Transfer in Global Perspective. Aldershot: Ashgate.

Fairclough, Norman. 2006. Discourse and Social Change. Cambridge: Polity.

Freeman, Richard. 1999. "Policy Transfer in the Health Sector: A Working Paper." University of Edinburgh. http://citeseerx.ist.psu.edu/viewdoc/download ?doi $=10.1 \cdot 1 \cdot 202.5374 \& \mathrm{rep}=$ rep1\&type $=$ pdf.

Friedman, Thomas L. 2005. The World Is Flat: A Brief History of the Twenty-First Century. New York: Farrar.

Ghemawat, Pankhaj. 2011. World 3.0: Global Prosperity and How to Achieve It. Boston: Harvard Business Press.

Government of Bahamas. 1994. "Draft Education Policy." Ministry of Education, Bahamas.

Grugel, J., and A. Payne. 2000. "Regionalist Responses in the Caribbean Basin.” In National Perspectives on the New Regionalism in the South, ed. B. Hettne, A. Inotai, and O. Sunkel. New York: Palgrave Macmillan. 
Haas, Peter M. 1992. "Introduction: Epistemic Communities and International Policy Coordination." International Organization 46 (1): 1-35.

Hall, Kenneth O., ed. 2003. Re-inventing CARICOM: The Road to a New Integration. Kingston: Ian Randle.

Ikenberry, John G. 1990. "The International Spread of Privatization Policies: Inducement, Learning, and Policy Bandwagoning." In The Political Economy of Public Sector Reform and Privatization, ed. E. N. Suleiman and J. Waterbury. Boulder, CO: Westview.

Jakobi, Anja P. 2009 "Global Education Policy in the Making: International Organisations and Lifelong Learning." Globalisation. Societies and Education 7 (4): 473-87. doi:10.1080/14767720903412275.

Jones, Phillip W. 2004. "Taking the Credit: Financing and Policy Linkages in the Education Portfolio of the World Bank." In The Global Politics of Educational Borrowing and Lending, ed. G. Steiner-Khamsi. New York: Teachers College Press.

Jules, Tavis D. 2008. "Re/Thinking Harmonization in the Commonwealth Caribbean: Audiences, Actors, Interests, and Educational Policy Formation.” EdD diss., Teachers College, Columbia University.

Jules, Tavis D. 2012. Neither World Polity nor Local or National Societies. Frankfurt: Peter Lang Internationaler Verlag der Wissenschaften.

Jules, Tavis D. 2013. "Ideological Pluralism and Revisionism in Small (and Micro) States: The Erection of the Caribbean Education Policy Space." Globalisation. Societies and Education 11 (2): 258-75. doi:10.1080/14767724.2013.782194.

Kerr, Clark. 1983. The Future of Industrial Societies: Convergence or Continuing Diversity? Cambridge, MA: Harvard University Press.

Krasner, S. D. 1983. International Regimes. Ithaca, NY: Cornell University Press.

Luhmann, Niklas, and Karl-Eberhard Schorr. 1979. Reflexionsprobleme im Erziehungswesen. Stuttgart: Klett-Cotta.

Meyer, John W., John Boli, George M. Thomas, and Francisco O. Ramirez. 1997. "World Society and the Nation-State." American Journal of Sociology 103 (1): 141-81.

Meyer, John W., and Francisco O. Ramirez. 2000 "The World Institutionalization of Education-Origins and Implications." In Discourse Formation in Comparative Education, ed. J. Schriewer. Frankfurt: Lang.

Meyer, John W., David Tyack, Joane P. Nagel, and Audri Gordon. 1979. "Public Education as Nation- Building in America." American Journal of Sociology 85:978-86.

Mundy, Karen. 1998. "Education Multilateralism and World Disorder." Comparative Education Review 42 (4): 448-78.

Nòvoa, Antonio, and Martin Lawn. 2002. Fabricating Europe: The Formation of an Education Space. Dordrecht: Kluwer Academic.

Phillips, David. 2004. "Toward a Theory of Policy Attraction in Education." In Lessons from Elsewhere: The Politics of Educational Borrowing and Lending, ed. G. SteinerKhamsi. New York: Teachers College Press.

Ramirez, Francisco O., and John Boli. 1987. "The Political Construction of Mass Schooling: European Origins and Worldwide Institutionalization." Sociology of Education 60:2-17.

Ramirez, Francisco O., and John W. Meyer. 2002. "National Curricula: World Models and National Historical Legacies." In Internationalisation: Comparing Educational Systems, ed. M. Caruso and H. E. Tenorth. Frankfurt: Lang. 
Robertson, Susan. L. 2010. “The EU, 'Regulatory State Regionalism' and New Modes of Higher Education Governance." Globalisation. Societies and Education 8 (1): 2337. doi:10.1080/14767720903574033.

Robertson, Susan L., and Roger Dale. 2008. "Researching Education in a Globalising Era: Beyond Methodological Nationalism, Methodological Statism, Methodological Educationism and Spatial Fetishism." In The Production of Educational Knowledge in the Global Era, ed. J. Resnik. Oxford: Sense.

Rose, Richard. 1993. Lesson-Drawing in Public Policy. Chatham, NJ: Chatham House. Schneider, Ann, and Helen Ingram. 1988. "Systematically Pinching Ideas: A Comparative Approach to Policy Design.” Iournal of Public Policy 8 (1): 61-80.

Schriewer, Jürgen. 1990. "The Method of Comparison and the Need for Externalization: Methodological Criteria and Sociological Concepts." In Theories and Methods in Comparative Education, ed. J. Schriewer and B. Holmes. New York: Lang.

Schriewer, Jürgen, ed. 2002. "Educación Comparada: un gran programa ante nuevos desafíos." In Formación del discurso en la educación comparada. Barcelona: Ediciones Pomares.

Schriewer, Jürgen. 2003. "Globalisation in Education: Process and Discourse." Policv Futures in Education 1 (2): 271-83. doi:10.2304/pfie.2003.1.2.6.

Schriewer, Jürgen, and Carlos Martinez. 2004. "Constructions of Internationality in Education." In The Global Politics of Educational Borrowing and Lending, ed. G. Steiner-Khamsi. New York: Teachers College Press.

SCME (Standing Committee of Ministers of Education). 1988. "Report of the Seventh Meeting of the Standing Committee of Ministers Responsible for Education." Report 88/7/53 SCME, CARICOM, Georgetown, Guyana.

Second Special Meeting of SCME. 1997. "Report of the Second Special Meeting of the Standing Committee of Ministers Responsible for Education (REP.97/2/69 SCME [Spec.])." Bridgetown: CARICOM.

Silova, I., and D. Hobson. 2014. Globalizing Minds: Rhetoric and Realities in International Schools. Greenwich, CT: Information Age Publishing.

Simons, Maarten, M. E. H. Olssen, and Michael A. Peters. 2009. Re-reading Education Policies: A Handbook Studying the Policy Agenda of the 21st Century. Vol. 32. Boston: Sense.

Special Meeting SCME. 1993. "Report of the Second Special Meeting of the Standing Committee of Ministers Responsible for Education (1993/1/38/REP/ME [Spec.]). SCME, CARICOM, Georgetown, Guyana.

Steiner-Khamsi, Gita. 2000. "Transferring Education, Displacing Reforms.” In Discourse Formations in Comparative Education, ed. J. Schriewer. New York: Lang.

Steiner-Khamsi, Gita. 2003. "The Politics of League Tables." Journal of Social Science Education 1. http://www.jsse.org/index.php/jsse/article/view/470.

Steiner-Khamsi, Gita. 2004. The Global Politics of Educational Borrowing and Lending. New York: Teachers College Press.

Steiner-Khamsi, Gita, and Ines Stolpe. 2006. Educational Import in Mongolia: Local Encounters with Global Forces. New York: Palgrave Macmillan.

Stone, Dinae. 1999. "Learning Lessons and Transferring Policy across Time, Space, and Disciplines." Politics 19 (1): 51-59.

Thomas, George M., John W. Meyer, Francisco O. Ramirez, and John Boli. 1987. Institutional Structure: Constituting State, Society, and the Individual. Newbury Park, CA: Sage. 
UNESCO. 1990. World Declaration on Education for All. Paris: UNESCO.

Vavrus, F., and M. Seghers. 2010. "Critical Discourse Analysis in Comparative Education: A Discursive Study of 'Partnership' in Tanzania's Poverty Reduction Policies." Combarative Education Review 54 (1): 77-103.

Verger, Antoni. 2008. "Measuring Educational Liberalization: A Global Analysis of GATS." Globalisation. Societies and Education 6 (1): 13-31.

Verger, Antoni, and Javier Pablo Hermo. 2010. "The Governance of Higher Education Regionalisation: Comparative Analysis of the Bologna Process and MERCOSUREducativo." Globalisation. Societies and Education 8 (1): 105-20.

Verger, Antoni, Mario Novelli, and Hulya Kosar Altinyelken. 2012. "Global Education Policy and International Development: An Introductory Framework.” In Global Education Policy and International Development: New Agendas, Issues and Policies. Huntington: Bloomsbury.

Weber, Robert Philip. 1990. Basic Content Analysis. Vol. 49. Beverly Hills, CA: Sage.

World Bank. 1990. Education for All. Washington, DC: World Bank. http://web.world bank.org/wbsite/external/topics/exteducation/0,contentmdk:20374062 menupk :540090 pagepk:148956 pipk:tates. 